\title{
Influence of weather conditions on the formation of the components of the chemical composition of cherry fruits
}

\author{
Vasylyshyna O. ${ }^{1}$, Postolenko Ye. ${ }^{2}$ \\ ${ }^{1}$ Uman National University of Horticulture, 1 Instytutska Str., Uman, Cherkasy oblast, 20305, Ukraine \\ ${ }^{2}$ Research Station of the Pomology named after L.P. Symyrenko, 9 Symyrenka Str., Mliiv-1 village, \\ Horodyshche region, Cherkasy oblast, 19512, Ukraine

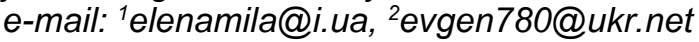

Goal. To determine the influence of weather conditions on the formation of the components of the chemical composition of cherry fruits. Methods. The study was carried out in 2016 - 2018 at the Experimental station named after L. P. Symyrenko of the Institute of horticulture of NAAS with cherry fruit of mid-season varieties Alpha and Pamiat Artemenka. The fruits were harvested in the first decade of July in the consumer stage of maturity. For the fruits they determined the following: the content of dry soluble substances using refractometer RPL- 3M; the total content of sugars - using ferricyanide method; the content of titrated acids - using titrometric method; the content of ascorbic acid — using iodometric method; the content of tannins and pigments - using the method of Neubauer and Leventhal. Results. Weather conditions at the phase of maturation influence the quality of cherry fruits. Strong and inverse correlation is fixed between the content of dry soluble substances and hydrothermal coefficient of the phase of ripening of fruits of cherry of variety Alpha $(-0,58 \pm 0,61)$ and variety Pamiat Artemenka $(-0,78 \pm 0,44)$. Strong connection $(0,94 \pm 0,23$ and $0.99 \pm 0,15)$ is observed between the content of tannins and pigments and the hydrothermal coefficient in the phase of ripening of fruits of cherry of varieties Alpha and Pamiat Artemenka. An important indicator of fruit quality of cherry is the content of titrated acids. Their formation is influenced by weather growing conditions. In particular, due to the considerable moisture in 2018, compared with 2016 and 2017, the content of titrated acids was higher on 14.5 and $15 \%$ for fruits of variety Alpha, and on 14 and $10 \%$ - for fruits of variety Pamiat Artemenka. Fall-out during the growing season and in the ripening phase strongly correlated with the content of titrated acids of fruits of varieties Alpha and Pamiat Artemenka with correlation coefficient $r=0,81 \pm 0.4$ and $r=0,94 \pm 0,23$, and $r=0,64 \pm 0,56$ and $r=0,39 \pm 0,74$. Conclusions. Equations of regression are built, which for the titrated coefficient of the ri- pening phase allow determining the content of dry soluble substances, tannins and pigments in the fruits of cherry of varieties Alpha and Pamiat Artemenka.

Key words: dry soluble substances, tannins, dyes, temperature, humidity, ripeness. DOI: https://doi.org/10.31073/agrovisnyk202002-05

Cherry is one of the most prevailing and ancient crops grown in Ukraine. It occupies the $2^{\text {nd }}$ place after the apple tree. Its fruits are rich in anthocyanins, flavonoids that cause red color [1].

Recently, most of the studies on the quality of cherry fruit in the literature are related to the study of anthocyanins and antioxidant activity. The presence of cherries in the fruits of which determines the healing properties. Cherry fruits are used as an anti-inflammatory agent, their use prevents colon cancer, gastric ulcers and bronchitis [2, 3].

In addition to anthocyanins, cherries are a source of polyphenols. The main ones are flavan-3-ol, hydroxycyanic acids. The content of polyphenols in cherry fruits is $1539.43-2982 \mathrm{mg} / 100 \mathrm{~g}$ of dry matter, with flavan-3-ol accounting for $40 \%$ of their total content [3].

Due to its rich chemical composition and unpretentious environmental conditions, cherry fruits are very prevailing in Europe, North America and Asia. Cherries are grown in Hungary, Poland, Romania, Turkey and Ukraine. Its production is growing every year, during 2006-2016 it increased from 1.14 million to 1.38 million tons. In 2017 and 2018, 172 and 219 thousand tons were produced. In 2019, 216 thousand tons of cherries were harvested in Ukraine. So, Ukraine ranked 3rd in the world rankings after Turkey and the USA.

The largest production of cherry fruit accounts for $-62 \%$ in Europe.

According to the US Department of Agriculture, global cherry production will decline slightly in the 2020 season. The main producers are Turkey (865 thousand tons), Chile (231), China (420), USA (450), EU countries (648 thousand tons) [4]. The cherry is adapted to the weather conditions in these countries, in particular withstands low temperatures in winter, and during flowering even the temperature $-2^{\circ} \mathrm{C}$ [5]. A small number of publications are devoted to the influence of weather conditions on the formation of cherry fruit quality [5-7].

Weather conditions for the cultivation of cherry fruits affect the formation of the fruit, size, structure, surface of the skin and wax layer, color, ripeness, the formation of taste, aroma of the fruit, chemical composition, organoleptic characteristics [6].

Depending on the weather conditions of the year, sugar growing in the fruit of cherries is $6.5-21.5 \%$, it is glucose $-3.8-5.3 \%$, fructose $-3.3-4.4 \%$, sucrose $-0.8 \%$. Acids in cherries account for $0.7-3.0 \%$, the main ones are malic and citric, as well as a small amount of amber, salicylic and formic. Tannins and dyes in cherry fruit 
make up $0,8 \%$ and affect the taste of the fruit. Cherries have a significant amount of $B$ vitamins: $B_{1}, B_{2}$ and PP, with vitamin $\mathrm{C}$ accounting for $10-50 \mathrm{mg} / 100 \mathrm{~g}$ [8-14].

According to A. Borowy, E. Chrzanowska, and M. Kaplan [15], 100g of fresh cherry fruits contain soluble solids $-14.4-23.1 \%$, including total carbohydrates $-10.9 \mathrm{~g}$, including digestible carbohydrates: glucose $-6.0-9.08 \mathrm{~g}$, fructose - 3.54-4.91; sucrose 0.4 ; cellulose $-1 \mathrm{~g}$; of vitamin $\mathrm{C}-3-12 \mathrm{mg}$. The weight of the fruit ranges from 3.4 to $7.17 \mathrm{~g}$.

When forming fruits, cherries play an important role in temperature resources and humidity. According to the research of M.O. Bagels, low temperatures $\left(-2,4^{\circ} \mathrm{C}\right)$ during flowering reduce the productivity of the variety. Increased temperatures $\left(33-37^{\circ} \mathrm{C}\right)$ and excess rainfall also adversely affect the yield due to damage to the fruit [16].

According to the research of in early ripe varieties, the A.M. Skinder-Barmina cherries last 39-48 days from the end of flowering to mass reaching, 49-57 days in the middle-ripe, 52-65 days in the late-ripe varieties. For full fruiting, sums of active temperatures above $10^{\circ} \mathrm{C}$ are required, in which the timing of fruiting cherries of early varieties is 5 days, from June 15 to June 20, medium-matured - 7 days from June 21 to June 28, and late ripening -14 days from June 29 to 13 July [17 -19].

According to L. Lakatos (2014), J. Revel (2009), the formation of fruit quality of cherries is affected by weather conditions, especially 10-15 days before the formation of the crop [6, 7].

In studies by L. Lakatos [5, 6] and others the influence of the climatic indicators of the period from flowering to reaching the fruits of cherry is shown: average maximum and minimum temperatures, humidity and their influence on the content of soluble solids, sugars, vitamin C. Studies have shown that increased rainfall during the period of reaching fruits contributed to less dry accumulation. The total rainfall was negatively correlated with the dry matter and acid content of cherry fruits.

The sugar content of the cherry fruit is positively correlated with the temperature of reaching. The higher the temperature $\left(11.5^{\circ} \mathrm{C}\right)$ on reaching, the higher the sugar content of the cherries. At very low temperatures, the sugar content of the cherries is low. In years with sufficient moisture supply, the content of vitamin $\mathrm{C}$ is higher [5, 6].

According to L. Lakatos, J. Revell, the average temperature in July correlates positively with the soluble solids content, and the precipitation in this month negatively correlates with the total sugar content [6, 7].

The purpose of research is to determine the influence of weather conditions on the formation of components of the chemical composition of cherry fruits.

Materials and methods of research. The studies were conducted in 2016-2018 at the L.P. Research Station. Simirenko Institute of Horticulture NAAS with cherries of mid-ripe varieties of Alpha and the Memory of Artemenko. The garden was planted in 2005 under the scheme $5 \times 3 \mathrm{~m}$. The planting width were under black steam, the access strips were treated with herbicide. The cherry fruits were harvested in the first decade of July, the consumer stage of ripeness.

To determine the qualitative composition of fruit cherries formed a sample weighing $2 \mathrm{~kg}$ of fruits of each variety, collected from 5 trees and different places of the crown. The fruits determined: the content of soluble solids on the RPL-3M refractometer, the total sugar content - ferricyanide method; titrated acids by the titrometric method; ascorbic acid - iodometric method, the content of tannins and dyes in the Neubauer and Leventhal method [20]. Repeat the experiment 3 times. Data were processed by the statistical analysis method of Statistica 6 (Mamchich, 2006) [21].

Research results. During 2016-2018, the agro-climatic indicators during the period of vegetation of cherry fruits differed (Table 1). The sum of effective temperatures was $417.4-615.8^{\circ} \mathrm{C}$. It was the highest in $2017(615.8$ $\left.{ }^{\circ} \mathrm{C}\right)$, the lowest in $2016\left(417.4^{\circ} \mathrm{C}\right)$. In the fruit-reaching phase, on the contrary, the sum of effective temperatures is lowest $-2017\left(139.7^{\circ} \mathrm{C}\right)$, and the highest $-2016\left(154.2^{\circ} \mathrm{C}\right)$. Increased and lowered temperature when reaching the fruits influenced the formation of their quality.

At the same time, the cherry precipitations significantly influence the formation of fruit quality with the temperature factor. During the years 2016-2018, the number of studies during the growing season amounted to $204.3-312.2 \mathrm{~mm}$. According to the years of research, the greatest rainfall occurred during the growing season $2018-312.2 \mathrm{~mm}$, and the smallest in 2016-204.3 $\mathrm{mm}$.

\section{Agroclimatic indicators for the period of vegetation of cherries}

\begin{tabular}{|c|c|c|c|c|c|c|c|}
\hline \multirow{3}{*}{ Year } & \multirow{3}{*}{$\begin{array}{l}\text { Vegetation } \\
\text { period, days }\end{array}$} & \multicolumn{2}{|c|}{$\begin{array}{l}\text { Sum of effective } \\
\text { temperatures, }{ }^{\circ} \mathrm{C}\end{array}$} & \multicolumn{2}{|c|}{ Precipitation, mm } & \multicolumn{2}{|l|}{ GTC } \\
\hline & & \multirow{2}{*}{ 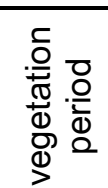 } & $\begin{array}{l}\text { achievement } \\
\text { phase }\end{array}$ & \multirow{2}{*}{ 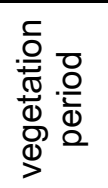 } & $\begin{array}{c}\text { achievement } \\
\text { phase }\end{array}$ & \multirow{2}{*}{ 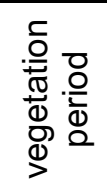 } & $\begin{array}{c}\text { achievement } \\
\text { phase }\end{array}$ \\
\hline & & & 15 days & & 15 days & & 15 days \\
\hline 2016 & 85 & 417,4 & 154,2 & 204,3 & 34,7 & 4,9 & 2,3 \\
\hline 2017 & 87 & 615,8 & 139,7 & 265,8 & 23,5 & 4,3 & 1,7 \\
\hline 2018 & 90 & 593,4 & 148,4 & 312,2 & 36,6 & 5,2 & 2,5 \\
\hline
\end{tabular}


In the achievement phase, this trend is the same: the highest rainfall in 2018 is $36.6 \mathrm{~mm}$, the lowest in 2017 is $23.5 \mathrm{~mm}$.

The most complete assessment of the influence of weather conditions on the formation of fruit quality is given by hydrothermal coefficient (GTC). During the growing season it was at the level of 4.3-5.2. It is the highest in 2018 (5.2) and the lowest in 2017 (4.3). During the achievement phase, the indicator was 1.7-2.5.

It is obvious that humidity and thermal resources during the years of research influenced the formation of cherry fruit quality (Fig. 1). In 2017, compared to 2018 and 2016, the solids content of cherries of the experimental varieties Alfa and Memory of Artemenko was higher by $1.8-5.6 \%$ and $7-12.12 \%$. This is due to the weather conditions of the reaching phase: a lower sum of temperatures in $2017\left(139.7^{\circ} \mathrm{C}\right)$, compared to other years of research (154.2 and $148.4^{\circ} \mathrm{C}$ ), a small amount of rainfall of $23.5 \mathrm{~mm}$, which led to the lowest SCC among the years under review -1.7 . The obtained data also confirm the results of studies by foreign authors [6].

Consequently, temperature and precipitation during the cherry fruiting phase are significantly influenced by the formation of soluble solids content. The correlation between these indicators makes it possible to establish a GTC. For the cherry fruit, during the 2017 growing season, it is the lowest at 4.3, while the highest in 2018 is 5.2. During the phases of achievement, the GTC trend is similar.

The correlation between the chemical composition of cherry fruits and the weather conditions most closely reflects the relationship of these indicators (Table 2, Fig. 1).
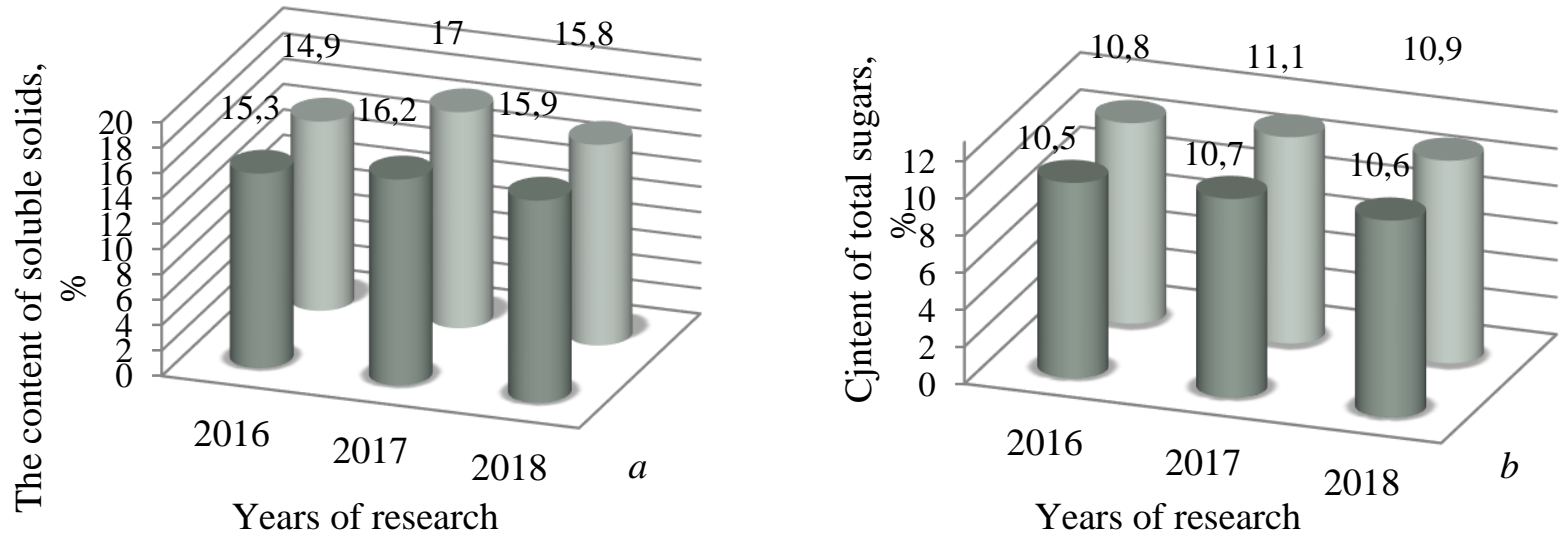

Fig. 1. Content of cherry fruits: a - dry soluble substances $\left(N_{I R} R_{05}=0.3\right) ; b-$ total sugars $\left(N I R_{05}=0,2\right)$; - Alpha; $\square$ - The memory of Artemenko

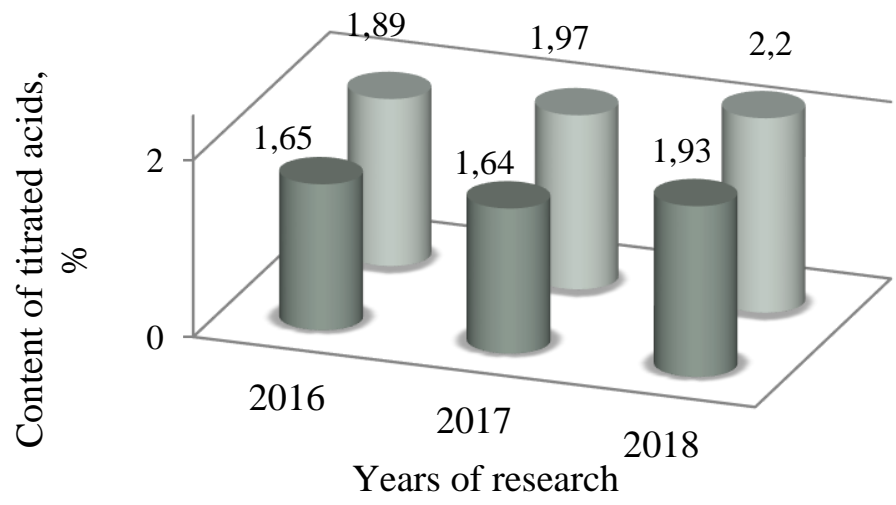

Fig. 2. The content of titrated acids in cherry fruits $\left(N I R_{05}=0.1\right)$; Artemenko

Alpha; $\square$ - Memory of 

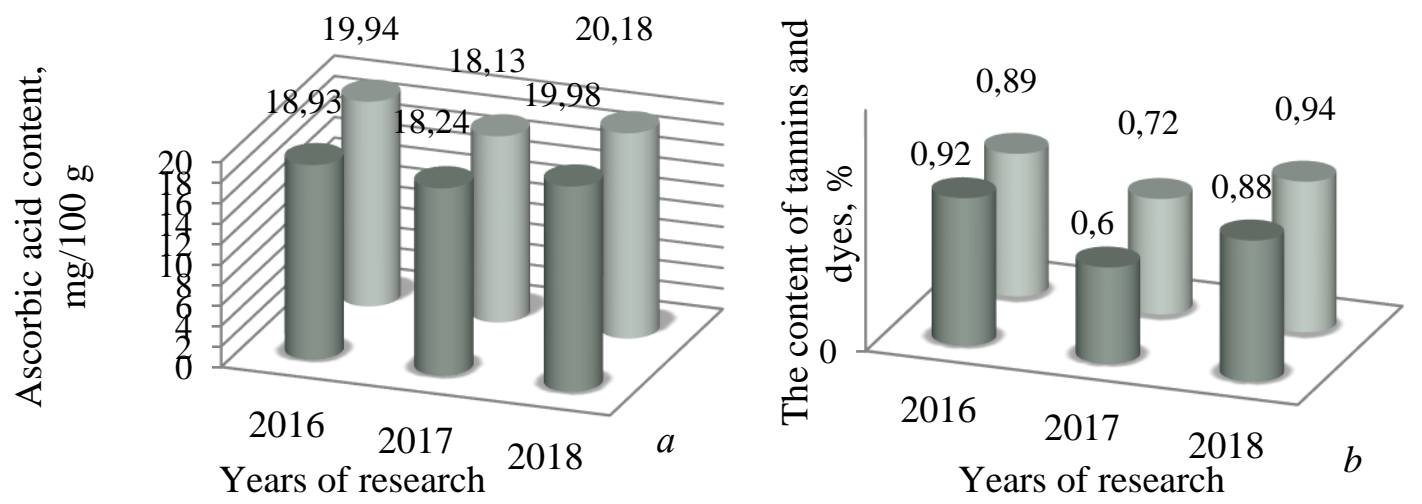

Fig. 3. Fruit content of cherries: a - ascorbic acid $\left(N I R_{05}=0,4\right) ; b-$ tannins and colorants $\left(N_{I R}=0,02\right) \square-A l p h a ; \square-M e m o r y$ of Artemenko

A significant strong relationship was found between the sum of effective temperatures, the content of soluble solids and sugars in cherry fruits and correlation coefficients were derived. For cherries of the Alpha variety $r=$ $0.97 \pm 0.15$ and $r=0.91 \pm 0.27$, Memory of Artemenko $r=0.88 \pm 0.32$ and $r=0.82 \pm 0.39$. A strong correlation is also found between the temperature of the reaching phase and the solids content or sugars of cherry fruits of both varieties. With correlation coefficients for cherry fruit, Alpha varieties $r=-0.95 \pm 0.19$ and $r=-0.99 \pm 0.07$ and Memory of Artemenko $r=-0.99 \pm 0.02$.

2. Correlation between weather conditions and content of some components of the chemical composition of cherry fruits

\begin{tabular}{|c|c|c|c|c|c|c|c|}
\hline \multirow{2}{*}{ Index } & \multirow{2}{*}{ Grade } & \multicolumn{2}{|c|}{$\begin{array}{l}\text { Sum of effective } \\
\text { temperatures, }{ }^{\circ} \mathrm{C}\end{array}$} & \multirow{2}{*}{ 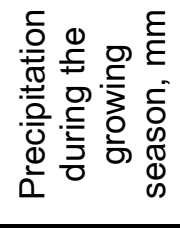 } & \multirow{2}{*}{ 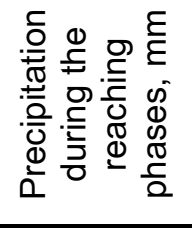 } & \multirow{2}{*}{ 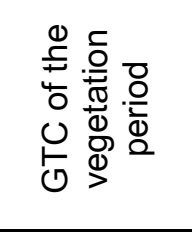 } & \multirow{2}{*}{ 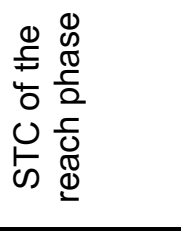 } \\
\hline & & $\begin{array}{l}\text { during the } \\
\text { growing } \\
\text { season }\end{array}$ & $\begin{array}{c}\text { during the } \\
\text { achievement } \\
\text { phase }\end{array}$ & & & & \\
\hline \multirow{2}{*}{$\begin{array}{l}\text { Soluble } \\
\text { solids }\end{array}$} & Alpha & $0,97 \pm 0,15$ & $-0,95 \pm 0,19$ & $0,71 \pm 0,49$ & $-0,66 \pm 0,54$ & $-0,50 \pm 0,67$ & $-0,58 \pm 0,61$ \\
\hline & $\begin{array}{c}\text { Artemenko } \\
\text { Memory }\end{array}$ & $0,88 \pm 0,32$ & $-0,99 \pm 0,02$ & $0,50 \pm 0,67$ & $-0,84 \pm 0,37$ & $-0,72 \pm 0,49$ & $-0,78 \pm 0,44$ \\
\hline \multirow[b]{2}{*}{ Total sugar } & Alpha & $0,91 \pm 0,27$ & $-0,99 \pm 0,07$ & $0,57 \pm 0,62$ & $-0,79 \pm 0,42$ & $-0,65 \pm 0,55$ & $-0,72 \pm 0,27$ \\
\hline & $\begin{array}{c}\text { Artemenko } \\
\text { Memory }\end{array}$ & $0,82 \pm 0,39$ & $-0,99 \pm 0,05$ & $0,40 \pm 0,74$ & $-0,89 \pm 0,29$ & $-0,79 \pm 0,43$ & $-0,84 \pm 0,37$ \\
\hline \multirow{2}{*}{$\begin{array}{l}\text { Titrated } \\
\text { acids }\end{array}$} & Alpha & $0,38 \pm 0,75$ & $0,14 \pm 0,90$ & $0,81 \pm 0,4$ & $0,64 \pm 0,56$ & $0,78 \pm 0,44$ & $0,71 \pm 0,49$ \\
\hline & $\begin{array}{c}\text { Artemenko } \\
\text { Memory }\end{array}$ & $0,62 \pm 0,57$ & $-0,14 \pm 0,91$ & $0,94 \pm 0,23$ & $0,39 \pm 0,74$ & $0,57 \pm 0,61$ & $0,49 \pm 0,67$ \\
\hline \multirow{2}{*}{$\begin{array}{l}\text { Ascorbic } \\
\text { acid }\end{array}$} & Alpha & $-0,95 \pm 0,19$ & $0,97 \pm 0,15$ & $-0,66 \pm 0,54$ & $0,71 \pm 0,5$ & $0,56 \pm 0,62$ & $0,63 \pm 0,56$ \\
\hline & $\begin{array}{c}\text { Artemenko } \\
\text { Memory }\end{array}$ & $, 92 \pm 0,26$ & $0,99 \pm 0,08$ & $-0,58 \pm 0,61$ & $0,79 \pm 0,42$ & $0,65 \pm 0,55$ & $0,72 \pm 0,49$ \\
\hline \multirow{2}{*}{$\begin{array}{c}\text { Tannins and } \\
\text { dyes }\end{array}$} & Alpha & $-0,68 \pm 0,53$ & $0,96 \pm 0,19$ & $-0,19 \pm 0,88$ & $0,97 \pm 0,16$ & $0,90 \pm 0,29$ & $0,94 \pm 0,23$ \\
\hline & $\begin{array}{c}\text { Artemenko } \\
\text { Memory }\end{array}$ & $-0,39 \pm 0,74$ & $0,81 \pm 0,39$ & $0,14 \pm 0,91$ & $0,99 \pm 0,05$ & $0,99 \pm 0,07$ & $0,99 \pm 0,15$ \\
\hline
\end{tabular}

Precipitation during the growing season had less effect on solids and sugars than temperature. For the cherries of the varieties of Alpha and Memory of Artemenko, their number was strongly correlated with the content of soluble solids $(r=0.5 \pm 0.67-0.71 \pm 0.49)$. While the content of sugars correlation dependence is average. During the precipitation phase, a strong inverse correlation dependence with the soluble solids content with a correlation coefficient $r=-0.66 \pm 0.54$ and $r=-0.84 \pm 0.37$ was found.

Between the rainfall during the cherry fruiting phase and the sugar content, the correlation dependence is also strong and reversed $(r=-0.79 \pm 0.42$ and $r=-0.89 \pm 0.29)$. The rainfall/temperature ratio makes it possible to more fully determine the effect of climatic indicators on cherry fruit formation. A strong inverse correlation was 
established between the GTC of the reaching phase and the soluble solids content of the cherries of the Alpha and Memory of Artemenko ( $r=-0.58 \pm 0.61$ and $r=-0.78 \pm 0,44)$. There is also a strong and inverse relationship between the GTC of the reaching phase and the sugar content $(r=-0.72 \pm 0.27$ and $r=-0.84 \pm 0.37)$.

An important indicator of the quality of cherry fruits is the content of titrated acids. Their formation is influenced by the weather conditions of cultivation (Fig. 2). In particular, with significant humidity in 2018, compared to 2016 and 2017, the content of titrated acids is higher for the fruits of cherries Alpha varieties by 14.5 and $15 \%$, Memory of Artemenko -14 and $10 \%$.

Precipitation during the growing season and during the reaching phases is strongly correlated with the content of titrated acids of the fruits of cherry Alpha and Memory of Artemenko with correlation coefficients $r=0.81 \pm 0.4$ and $r=0.94 \pm 0.23$ and $r=0.64 \pm 0.56$ and $r=0.39 \pm 0.74$ (Fig. 3). The GTC of the growing season is also significant $(r=0.78 \pm 0.44$ and $r=0.57 \pm 0.61)$.

The content of biologically active substances of cherry fruits depends on the weather conditions of the year of cultivation (Fig. 3). In particular, in 2018, ascorbic acid is accumulated in cherries with high moisture content (36.6 $\mathrm{mm}$ ) during the reaching and low temperatures phases $\left(148.4^{\circ} \mathrm{C}\right.$ ), compared to 2016 and 2017 for Memory of Memory of Artemenko and Alpha is up by $1-10 \%$ and $5-7 \%$. This is evidenced by the rather high correlation coefficient between the content of ascorbic acid and GTC of cherry fruits $(r=0.63 \pm 0.56$ and $r=0.72 \pm 0.49)$.

Cherry fruits are valued for their high content of tannins and colorants (see Figure 3). On average, during the years of research, their content in the variety Alpha was $0.8 \%$, in Memory of Artemenko $-0.85 \%$. The lowest content $(0.6-0.72 \%)$ was observed in 2017 with low precipitation during the reaching phases $(23.5 \mathrm{~mm})$ and the sum of temperatures $\left(139.7^{\circ} \mathrm{C}\right)$. While in significant rainfall and temperatures in 2018 and 2016 , the content of tannins and dyes of the fruit of the Alpha variety is higher by $46-53 \%$, the Memory of Artemenko by $23-30 \%$. The GTC of the achievement phase is quite strong $(r=0.94 \pm 0.23$ and $0.99 \pm 0.15)$ and indicates a close correlation dependence.

The correlation dependences of the influence of weather conditions on the content of ascorbic acid and tannins and dyes of cherry fruits have been determined by studies of foreign authors $[6,7]$.

A strong correlation between the soluble solids content and the GTC of the period of reaching the fruits of cherry varieties Alpha and Artemenko Memory is revealed, and a regression equation is found, which allows the GTC to determine the soluble solids content (Fig. 4).
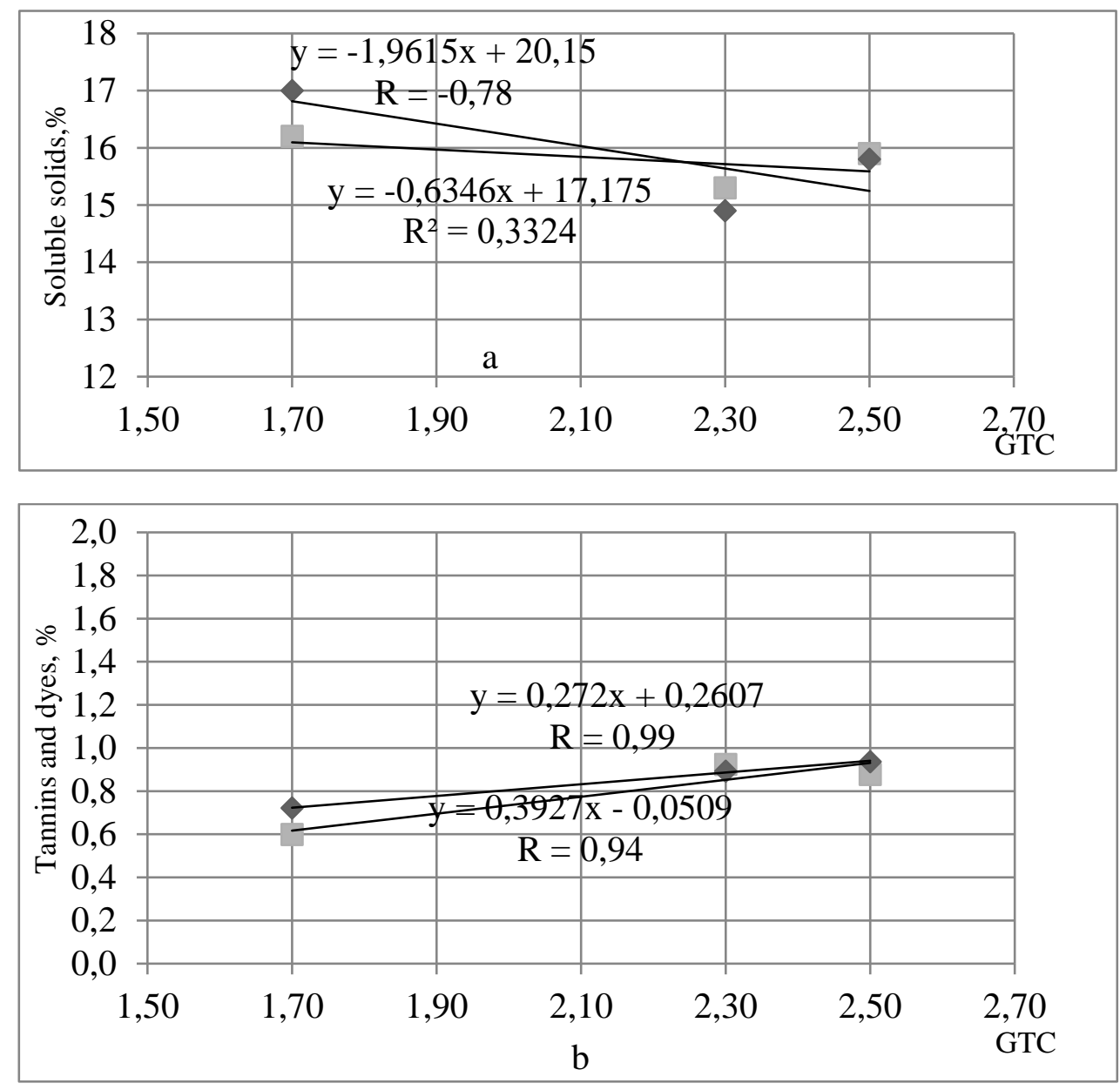

Fig. 4. The content of cherry fruits, depending on the GTC, the period of reaching: - dry soluble substances; - tannins and dyes; - Alpha; - the Memory of Artemenko 
Because cherry fruits are valuable in the content of tannins and dyes, a strong correlation is found between them and the GTC of the period of reaching. Equations that allow the prediction of the content of tannins and dyes on the basis of GTC are derived.

\section{Conclusions}

Weather conditions of the reach phase affect the quality of cherry fruits. A strong and inverse correlation between the soluble solids content and the SCC of the fruiting phase of cherry Alpha varieties $(-0.58 \pm 0.61)$ and Memory of Artemenko $(-0.78 \pm 0,44)$ was established. There is a strong $(0.94 \pm 0.23$ and $0.99 \pm 0.15)$ relationship between the content of tannins and dyes and the GTC of the fruiting phase of cherry blossoms Alpha and Memory of Artemenko. The regression equation for which the content of dry soluble, tannic and color substances in the fruits of cherries of the varieties Alpha and Memory of Artemenko can be predicted by the SCC of the achievement phase.

\section{References}

1. Kasım, R., Sülüsoğlu M., \& Ufuk Kasım, M. (2011). Relationship between total anthocyanin level and color of natural cherry laurel (Prunus laurocerasus L.) fruits. African Journal of Plant Science, 5 (5), 323-328.

2. Wojdyło, A., Nowicka, P., Laskowski, P., \& Oszmiański, J. (2014). Evaluation of sour cherry (Prunus cerasus L.) fruits for their polyphenol content, antioxidant properties, and nutritional components. Journal of Agreculturul and Food Chemistry, 62 (51), 12332-12345.

3. Blando, F., Gerardi, C., \& Nicoletti, I. (2004). Sour Cherry (Prunus cerasus L.) anthocyanins as ingredients for functional foods. Journal of biomedicine and biotechnology, 5, 253-258.

4. Blando, F., \& Dave Oomah, B. (2019). Sweet and Sour Cherries: Origin, Distribution, Nutritional Composition and Health Benefits. Trends in Food Science \& Technology, 86, 517-529. https://doi.org/10.1016/j.tifs.2019.02.052.

5. Lakatos, L., Szabó, T., Sun, Z., Soltész, M., Szabó, Z., Dussi, M.C., \& Nyéki, J. (2010). The role of meteorological variables of blossoming and ripening within the tendency of qualitative indexes of sour cherry. International Journal of Horticultural Science, 16 (1), 7-10.

6. Lakatos, L., Dussi, M.C., \& Szabo, Z. (2014). The influence of meteorological variables on sour cherry quality parameters. Acta horticulturae, 1020, 287-292. doi: 10.17660/ActaHortic.2014.1020.41.

7. Revell, J. (2009). Sensory profile and consumer acceptability of sweet cherries. UK: University of Nottingham.

8. Caprio, J. M., \& Quamme, H. A. (2006). Influence of weather on apricot, peach and sweet cherry production in the Okanagan Valley of British Columbia. Canadian journal of plant science, 86 (1), 259-267. doi: 10.4141/P05-032.

9. Ivanova, T. G., Ivanova, I. Ye., Bezkorovajnij, O. S., \& Todorova, L. V. (2008). Perspektivnij sort vishni z optimal'nim kompleksom fiziko-biohimichnih vlastivostej plodiv [Promising variety of cherries with optimal complex of physico-biochemical properties of fruits]. Gardening, 61, 245-250. [In Ukrainian].

10. Kolesnikova, A. F. (2003). Vishnja i chereshnja [Cherry and sweet cherry] Moscow: Folio. [In Ukrainian].

11. Poll, L., Petersen, M., \& Nielsen, G. S. (2003). Influence of harvest year and harvest time on soluble solids, titrateable acid, anthocyanin content and aroma components in sour cherry (Prunus cerasus L. cv. "Stevnsbær"). European food research and technology, 216 (3), 212-216. doi: 10.1007/s00217-002-0641-8.

12. Vasylyshyna, O. (2016). Inflaence of freezing and storing cherry fruit on its nutritional value. Acta scientiarum polonorum technologia alimentaria, 15 (2), 145-150. doi: 10.17306/J.AFS.2016.2.14.

13. Pedisic, S., Levaj, B., Dragovic Uzelac, V., \& Kos, K. (2007). Physicochemical composition, phenolic content and antioxidant activity of sour cherry cv. Marasca during ripening. Agriculturae conspectus scientificus, 72 (4), 295-300.

14. Milosevic, T., \& Milosevic, N. (2012). Fruit Quality Attributes of Sour Cherry Cultivars. Agronomy. doi: $10.5402 / 2012 / 593981$.

15. Borowy, A., Chrzanowska, E., \& Kaplan, M. (2018). Comparison of three sour cherry cultivars grown in central-eastern Poland. Acta scientiarum polonorum hortorum cultus, 17 (1), 63-73. doi: 10.24326 / asphc.2018.1.6.

16. Bublyk, M. O. (2002). Zonal'ne rajonuvannja vishni i slivi v Ukraïni [Zoning of Cherries and Plums in Ukraine]. Garden, grapes and wine, Ukraine, 9, 20-24. [In Ukrainian].

17. Shkinder-Barmina, A. N. (2013). Sortovye osobennosti razvitija vishni (Cerasus vulgaris Mill.) na juge Ukrainy [Varietal features of the development of cherries (Cerasus vulgaris Mill.) In the south of Ukraine]. Modern gardening, 3, 1-7. [In Ukrainian].

18. Shkinder-Barmina, A. N. (2015). Optimizacija sortimentu vishni (Cerasus Vulgaris Mill.) dlja stvorennja nasadzhen' v umovah pivdennogo stepu Ukraïni [Optimization of assortment of cherries (Cerasus vulgaris Mill) for planting in the conditions of the Southern Steppe of Ukraine]. Gardening, 70, 15-21. [In Ukrainian].

19. Shkinder-Barmina, A. M., Turovceva, V. O, \& Turovceva, N. M. (2011). Perspektivni sorti vishni institutu zroshuval'nogo sadivnictva imeni M.F. Sidorenka M.F. NAAN [Promising Cherry Varieties of the Irrigation Horticulture Institute Sidorenko NAAN]. Biological Bulletin of Melitopol State Pedagogical University, 3, 73-79. [In Ukrainian]. 
20. Naychenko, V. M. Praktykum z tekhnolohii zberihannia i pererobky plodiv ta ovochiv [Workshop on the technology of storing and processing fruits and vegetables]. Kyiv: Shkoljar, 2001. [In Ukrainian].

21. Mamchich, T. I., Olenko, A. Ya., Osipchuk, M. M., \& Shportyuk, V. G. (2006). Statistichnij analiz danih z paketom STATISTICA [Statistical analysis of data with STATISTICA package]. Drohobych. [In Ukrainian]. 